\title{
PENINGKATAN PRAKTEK GIZI SEIMBANG DAN PHBS PADA MURID SEKOLAH DASAR
}

\author{
Saifuddin Sirajuddin ${ }^{1}$, Masni ${ }^{2}$, Ulfah Najamuddin ${ }^{1}$ \\ ${ }^{1}$ Bagian Ilmu Gizi, Fakultas Kesehatan Masyarakat Universitas Hasanuddin \\ ${ }^{2}$ Bagian Biostatistik, Fakultas Kesehatan Masyarakat Universitas Hasanuddin
}

Korespndensi : saifuddin59@yahoo.com dan HP: +6285399796462

\begin{abstract}
Short and thin nutritional problems faced by students in Cambaya Elementary School in Makassar City are still high at $39.4 \%$ and $23.1 \%$ respectively. Breakfast habits that are very low at only $22.1 \%$ have the potential to cause stunted growth and development of the child's brain, which has implications for the decrease in intelligence of the child. This research aims to improve the knowledge, motivation, and skills of parents and teachers about balanced nutrition of school children and improving students' practice and motivation in a clean and healthy environment. The research uses quasi-experimental methods with pre and post test designs. The population in this study were 50th grade students of the Makassar Cambayya state primary school. Implementation of activities in the form of lectures, discussions, balanced nutrition practices and PHBS. Knowledge, motivation, skills about balanced nutrition and PHBS were measured using a questionnaire. Assessment is carried out before and shortly after giving counseling and a week after giving counseling. The results of this service are based on the Wilcoxon test. It is known that there is a significant increase in knowledge before and shortly after giving counseling $p=0.039(p<0.05)$ and a decrease in knowledge a week after counseling $p=0.011$ ( $p<0.05)$. Suggestions that can be given to the school should be active in conveying information about PHBS to school children.
\end{abstract}

Keywords: Balanced nutrition, PHBS, Knowledge

\section{PENDAHULUAN}

Institusi pendidikan dipandang sebagai sebuah tempat yang strategis untuk mempromosikan kesehatan, sekolah juga merupakan institusi yang efektif untuk mewujudkan pendidikan kesehatan, dimana peserta didik dapat diajarkan tentang maksud perilaku sehat dan tidak sehat serta konsekuensinya. Selain itu, usia sekolah termasuk kelompok usia dini merupakan masa keemasan untuk menanamkan prinsip-prinsip gizi seimbang dan berpotensi sebagai agent of change di lingkungan sekolah, keluarga, maupun masyarakat.

Usia sekolah sangat peka untuk menanamkan pengertian dan kebiasaan hidup sehat, keadaan kesehatan anak sekolah akan sangat berpengaruh terhadap prestasi belajar yang dicapai. Pendidikan kesehatan melalui anak-anak sekolah sangat efektif untuk merubah perilaku dan kebiasaan sehat umumnya. Usia anak didik yang biasa masuk bangku sekolah dasar baik negeri atau swasta yaitu 7-13 tahun.

Selain itu, usia anak sekolah merupakan masa yang krusial bagi 
pertumbuhan dan perkembangan murid di masa yang akan datang. Pemenuhan gizi yang tepat, optimal dan seimbang dapat mendukung pencapian generasi yang sehat dan berprestasi. Namun, pada masa tersebut, murid sekolah dasar diperhadapkan pada masalah gizi yang menghantui pertumbuhan dan perkembangan murid. Masalah gizi tersebut antara lain pendek (stunting), kurus, anemia, infeksi kecacingan, dan karies pada gigi, serta kegemukan pada usia dini. Kegemukan atau obesitas disebabkan karena konsumsi makanan yang melebihi kebutuhannya per hari. Sebaliknya, gagal tumbuh (pendek dan kurus) biasanya disebabkan karena kurangnya asupan gizi. Selain gagal tumbuh, kurangnya asupan gizi juga dapat menyebabkan terjadinya anemia dan membuat anak rentan terhadap infeksi. Karies disebabkan karena konsumsi makanan yang mengandung gula berlebihan disertai dengan kebersihan gigi yang kurang terjaga. Infeksi kecacingan disebabkan karena kurangnya kebiasaan cuci tangan saat makan dan seringnya tidak menggunakan alas kaki saat beraktifitas. Hasil riset kesehatan dasar tahun 2013 menunjukkan bahwa secara nasional prevalensi pendek pada anak umur 5-12 tahun adalah 30,7 persen $(12,3 \%$ sangat pendek dan $18,4 \%$ pendek) dan prevalensi kurus (menurut IMT/U) pada anak umur 512 tahun adalah 11.2 persen, terdiri dari 4,0 persen sangat kurus dan 7,2 persen kurus.

Orang tua murid dan guru dapat berperan aktif dalam mengatasi permasalah tersebut dengan memberikan stimulus kepada murid guna memperoleh status gizi yang baik. Hal ini dikarenakan status gizi murid sangat dipengaruhi oleh faktor asupan makanan dan penyakit infeksi yang diderita. Salah satu yang sering dilewatkan murid sebelum berangkat ke sekolah adalah sarapan pagi dan kebiasaan jajan tidak sehat/sembarangan di sekitar sekolah serta perilaku tidak bersih dan sehat. Stimulus yang dapat diberikan berupa peningkatan pengetahuan, skill, dan motivasi kepada murid. Pengetahuan, skill dan motivasi terkait perilaku gizi yang tepat dan seimbang dapat ditingkatkan dengan melibatkan orang tua murid, guru, dan murid tersebut dalam edukasi dan pendampingan kepada murid mengenai perilaku gizi seimbang.

Perilaku Hidup Bersih dan Sehat (PHBS) adalah sekumpulan perilaku yang dipraktikan atas dasar kesadaran sebagai hasil pembelajaran yang menjadikan seseorang atau keluarga yang dapat menolong diri sendiri di bidang kesehatan dan berperan aktif dalam mewujudkan kesehatan masyarakatnya. Perilaku Hidup Bersih dan Sehat terbagi atas berbagai tatanan, yaitu Tatanan Rumah Tangga, Institusi Pendidikan (Sekolah), Institusi Kesehatan, Tempat Kerja maupun Tempattempat Umum (Kemenkes, 2014).

Pendidikan kesehatan diartikan sebagai upaya dalam memberikan bimbingan kepada peserta didik tentang kesehatan secara menyeluruh baik secara fisik, mental dan sosial melalui kegiatan intrakurikuler dan ekstrakulikuler. Pembinaan lingkungan Sekolah sehat memungkinkan siswa dapat mencapai derajad kesehatan yang setinggi-tingginya untuk mencapai proses belajar yang maksimal (Kemendikbud, 2012). Perilaku Hidup Bersih dan Sehat di Sekolah adalah sekumpulan perilaku yang dipraktikan oleh peserta didik, guru dan masyarakat di lingkungan Sekolah atas dasar kesadaran sebagai hasil pembelajaran, sehingga secara mandiri mampu mencegah penyakit, meningkatkan kesehatan, serta berperan aktif dalam mewujudkan lingkungan sehat (Kemenkes, 2014).

Sekolah sehat harus memiliki lingkungan yang mendukung pembelajaran. Program ini menekankan pada aspek lingkungan yang meliputi lingkungan fisik dan non fisik. Aspek lingkungan fisik menekankan pada fasilitas seperti konstruksi ruang dan bangunan; ventilasi dan intensitas pencahayaan; kepadatan ruang kelas; jarak papan tulis 
dengan siswa; kualitas dan kuantitas meja dan kursi siswa; ketersediaan toilet, tempat cuci tangan, dan air bersih; pengendalian kebisingan; tempat sampah; program pengelolaan sampah; program pemberantasan bibit penyakit; serta kantin sehat. Lingkungan non fisik meliputi perilaku sehingga kriteria Sekolah sehat yang selanjutnya adalah Sekolah memiliki program pembinaan dalam mendorong dan membiasakan siswa untuk berperilaku hidup bersih dan sehat, yang tentu saja juga memberikan panutan kepada siswa (Kemendikbud, 2012).

Periku hidup bersih dan sehat (PHBS) untuk anak usia SD dimulai dengan membentuk kebiasaan sikat gigi dengan benar, mencuci tangan, serta membersihkan kuku dan rambut. PHBS yang sangat sederhana tersebut akan mengurangi risiko terkena penyakit. Penyakit yang akan muncul akibat rendahnya PHBS antara lain cacingan, diare, sakit gigi, sakit kulit, gizi buruk dan lain sebagainya yang pada akhirnya mengakibatkan rendahnya derajat kesehatan Indonesia (Pramono M, 2011).

Upaya untuk memberikan pengalaman belajar atau menciptakan suatu kondisi bagi perorangan, keluarga, kelompok dan masyarakat, dengan membuka jalur komunikasi, memberikan informasi dan melakukan edukasi untuk meningkatkan pengetahuan, sikap dan perilaku melalui pendekatan pimpinan (advocacy), bina suasana (social support) dan pemberdayaan masyarakat (empowerment) (Gani, 2013).

Berdasarkan analisis kecenderungan secara merata nasional, terdapat peningkatan proporsi penduduk berperilaku cuci tangan secara benar pada tahun $2013(47,0 \%)$ dibandingkan tahun 2007 (23,2\%). Demikian pula dengan perilaku BAB benar terjadi peningkatan dari $71,1 \%$ menjadi $82,6 \%$. Peningkatan tertinggi proporsi penduduk berperilaku cuci tangan benar terjadi di Bangka Belitung dengan besar kenaikan $(20,6 \%$ pada tahun 2007 menjadi 55,6\% pada
2013). Peningkatan terbesar proporsi penduduk berperilaku BAB benar terjadi di Sumatera Barat sebesar 14,8\% (Riskesdas, 2013).

Munculnya berbagai penyakit yang sering menyerang anak usia sekolah (usia 6-10), umumnya berkaitan dengan Perilaku Hidup Bersih dan Sehat (PHBS), Anak sekolah merupakan generasi penerus bangsa yang perlu di jaga, di tingkatkan dan dilindungi kesehatannya. Jumlah anak usia sekolah yang cukup besar yaitu $30 \%$ dari jumlah penduduk di Indonesia oleh karena itu, penanaman nilai-nilai PHBS disekolah merupakan kebutuhan mutlak bagi anak sekolah (Proverawati \& Rahmawati, 2012).

Pedoman Gizi Seimbang (PGS) adalah pedoman yang berisi susunan pangan sehari-hari yang mengandung zat gizi dalam jenis dan jumlah yang sesuai dengan kebutuhan. PGS menganjurkan empat pilar terkait perilaku gizi untuk diterapkan setiap hari. Empat pilar gizi seimbang tersebut adalah mengonsumsi aneka ragam pangan, berperilaku hidup bersih dan sehat (PHBS), melakukan aktivitas fisik, dan memantau berat badan secara teratur untuk mempertahankan berat badan normal (Kemenkes, 2014). Masalah konsumsi pangan yang belum sesuai dengan PGS tersebut dapat dipengaruhi oleh pengetahuan dan praktik gizi yang rendah. Sosialisasi PGS untuk anak sekolah diperlukan untuk mengatasi permasalahan tersebut. Anak sekolah menjadi sasaran kelompok masyarakat yang mudah dalam menerima dan menerapkan informasi baru (Amrah, 2013). Kegiatan sosialisasi PGS yang diberikan sejak dini akan memberikan dampak yang besar pada kesehatan anak di masa yang akan datang.

Praktik gizi dan pendidikan gizi merupakan salah satu prioritas utama di negara-negara maju. Istilah school feeding dikenal dan diterapkan untuk mengurangi kelaparan dan meningkatkan status gizi anak (Sinaga, 2016). School feeding dengan pengawasan ahli gizi memberikan 
dampak positif yaitu penurunan jumlah anak yang melewatkan sarapan dan peningkatan kualitas hidup anak (Tanaka dkk, 2015). Sistem school feeding di negara-negara maju belum dapat dikembangkan di semua sekolah di Indonesia. Oleh sebab itu, school feeding di Indonesia dapat disiasati dengan membawa makanan gizi sembang dari rumah. Pendidikan, pengetahuan, dan praktik gizi merupakan hal yang saling berhubungan. Pendidikan gizi penting diberikan kepada anak usia sekolah untuk meningkatkan pengetahuan gizi.

Berdasarkan hasil Penelitian sebelumnya di SD Cambaya oleh Saifuddin Sirajuddin dkk (2014) menunjukkan bahwa murid yang pendek dan kurus masih tinggi yakni masingmasing $39,4 \%$ dan $23,1 \%$. Asupan energi dan zat gizi makro yang lebih rendah dari kecukupannya masih tinggi yakni energi $74,03 \%$, protein $51,2 \%$, lemak $73,1 \%$, dan karbohidrat $71,2 \%$. Persentasi murid yang sarapan pagi sangat rendah yaitu $22,1 \%$. Anemia gizi yang ditemukan sangat tinggi yaitu sebesar $40 \%$. Prevalensi kecacingan pada murid SDN Cambaya tergolong cukup tinggi yaitu mencapai angka 57,7\%.

\section{BAHAN DAN METODE Lokasi Penelitian}

Penelitian ini dilakukan di sekolah dasar negeri cambayya Makassar.

\section{Desain dan Variabel Penelitian}

Jenis penelitian yang digunakan dalam penelitian ini adalah quasi eksperimen dengan pre test and post test.

\section{Populasi dan Sampel}

Sampel penelitian adalah siswa kelas 6 berjumlah 50 siswa.

\section{Pengumpulan Data}

Data primer diperoleh langsung dari responden dengan memberikan pertanyaan dalam bentuk kuesioner sebanyak 20 pertanyaan.

\section{Analisis Data}

Analisis data yang dilakukan secara univariat dilakukan pada masing-masing variabel untuk melihat gambaran umum distribusi dan frekuensinya.Sedangkan Uji bivariat dilakukan dengan membandingkan nilai sebelum dan sesudah diberikan penyuluhan dengan menggunakan uji $\mathrm{t}$ berpasangan. Selanjutnya data yang telah diperoleh akan disajikan dalam bentuk tabel dan grafik disertai dengan narasi.

\section{HASIL PENELITIAN \\ Karakteristik Responden}

Hasil analisis univariat menggambarkan distribusi responden berdasarkan karakteristik demografi responden (jenis kelamin dan kelas). Untuk karakteristik (Tabel 1) menurut jenis kelamin responden pada penelitian ini menunjukkan laki - laki berjumlah 20 responden $(40 \%)$ dan perempuan berjumlah 30 responden (60\%). Pada jumlah responden menurut kelas adalah $6 \mathrm{~A}$ berjumlah 28 responden $(58 \%)$ dan 6B berjumlah 22 responden (44\%).

\section{Analisis Deskriptif}

Tabel 3.

Perubahan Rerata Nilai Sebelum dan

Sesaat Setelah Pemberian Penyuluhan Tahun 2018

\begin{tabular}{ccc}
\hline Pre & Post & \multirow{2}{*}{ Nilai p } \\
\cline { 1 - 2 } mean \pm SD & mean \pm SD & \\
\hline $9,64 \pm 2,58$ & $10,34 \pm 2,29$ & 0,039
\end{tabular}

Berdasarkan Tabel 3 hasil penelitian menunjukkan bahwa nilai rerata sebelum pemberian penyuluhan adalah 9,64 dan terjadi peningkatan nilai rerata setelah pemberian penyuluhan adalah 10,34. Hasil uji statistik menunjukkan bahwa terdapat perbedaan signifikan antara sebelum dan sesaat setelah pemberian penyuluhan karena nilai $\mathrm{p}=$ $0,039(\mathrm{p}<0,05)$. 
Tabel 4.

Perubahan Rerata Nilai Sebelum dan Seminggu Setelah Pemberian Penyuluhan Tahun 2018

\begin{tabular}{cccc}
\hline Pre & Post sesaat & $\begin{array}{c}\text { Post 2 } \\
\text { minggu }\end{array}$ & $\begin{array}{c}\text { Nilai } \\
\mathrm{p}\end{array}$ \\
\cline { 1 - 3 } mean \pm SD & mean \pm SD & mean \pm SD & \\
& $10,34 \pm 2,29$ & $9,36 \pm 2,61$ & 0,011
\end{tabular}

Berdasarkan table 4 hasil penelitian menunjukkan bahwa nilai rerata setelah seminggu pemberian penyuluhan terjadi penurunan dengannilai rerata 9,36 dengan nilai statistik menunjukkan bahwa terdapat perbedaan signifikan yaitu $\mathrm{p}=0,011$ $(\mathrm{p}<0,05)$.

\section{PEMBAHASAN}

Teori yang dikemukakan oleh Notoadmojo (2007) penyuluhan kesehatan merupakan media promosi kesehatan yang dapat mempengaruhi pengetahuan seseorang. Beensley dan Fisher (2008) mengungkapkan bahwa pendidikan kesehatan memang menyampaikan informasi dengan harapan bahwa peserta didik akan mempelajarinya dan dapat mempengaruhi pengetahuannya. RISKESDAS (2010) juga mengatakan dengan adanya penyuluhan dapat meningkatkan pengetahuan, selain itu dapat mencegah fenomena penyimpangan kasus kesehatan reproduksi.

Pendidikan kesehatan untuk anak usia sekolah menggunakan metode dan media yang bermacam jenisnya. Ceramah, menyanyi, panggung boneka, games mengenai PHBS, serta masih banyak lagi. Namun, derajat kesehatan anak umur sekolah saat ini belum bisa dikatakan baik karena masih terdapat banyak masalah kesehatan khususnya pada anak sekolah yang umumnya berkaitan dengan PHBS. Kegiatan intervensi mengenai PHBS masih perlu dilakukan sebagai upaya untuk mengurangi masalah kesehatan anak umur sekolah yang berkaitan dengan PHBS. Intervensi yang dilakukan hendaknya dapat meningkatkan pengetahuan, sikap, dan tindakan mengenai PHBS. Menurut Notoatmodjo (2010), bahwasanya pengetahuan merupakan suatu unsur yang penting dalam upaya pembentukan tindakan seseorang. Pengetahuan diperlukan sebagai dorongan psikis dalam menumbuhkan sikap dan perilaku.

Usia seseorang mempengaruhi kemampuan seseorang untuk menerima informasi dan pola pikir seseorang terhadap informasi yang diberikan. Semakin bertambahnya usia maka kemampuan menerima informasi dan pola pikir seseorang semakin berkembang. Kemampuan seseorang untuk menerima informasi yang diberikan kepadanya berhubungan dengan maturitas dari fungsi tubuh baik indera maupun otak dan kesehatan seseorang.

Mayoritas responden berpendidikan SD artinya mayoritas tingkat pendidikan responden masih rendah. Salah satu faktor yang mempengaruhi pengetahuan adalah tingkat pendidikan, dimana tingkat pendidikan yang lebih tinggi mempengaruhi persepsi seseorang untuk mengambil keputusan dan bertindak (Notoatmodjo, 2007b)

Pendidikan memiliki peranan yang sangat penting dalam menentukan kualitas manusia, dengan pendidikan manusia memperoleh pengetahuan dan informasi. Semakin tinggi tingkat pendidikan seseorang maka akan semakin berkualitas hidupnya (Hurlock, 2007).

Reza et al menyebutkan semakin rendah tingkat pendidikan seseorang maka tingkat pengetahuan tentang personal higiene juga semakin rendah. Akibatnya menjadi kurang peduli tentang pentingnya personal higiene. Perlu program kesehatan umum untuk mendidik populasi mengerti aspek pencegahan penyakit.

Hasil penelitian ini menunjukkan adanya peningkatan nilai responden setelah dilakukan penyuluhan. Dilihat dari nilai rerata pre test yang lebih rendah daripada nilai rerata post test setelah penyuluhan. Hal ini menunjukkan bahwa penyuluhan tentang gizi seimbang dan PHBS memiliki 
peran menambah tingkat pengetahuan tentang gizi seimbang dan PHBS pada anak sekolah dasar.

Ada pengaruh penyuluhan terhadap peningkatan pengetahuan tentang gizi seimbang dan PHBS pada siswa sekolah dasar negeri cambayya makassar. Dengan adanya kekurangan dan kelemahan dari penelitian ini, penulis memberi saran sebaiknya ada penelitian lebih lanjut dengan mempertimbangkan pendidikan keluarga serta akses informasi yang didapat siswa mengenai gizi seimbang dan PHBS sehingga dapat digunakan sebagai referensi untuk penyusunan modul yang lebih lengkap tentang gizi seimbang dan PHBS yang sesuai untuk anak sekolah dasar.

\section{KESIMPULAN DAN SARAN}

Terjad peningkatan rerata nilai sesaat setelah pemberian penyuluhan serta penurunan rerata nilai seminggu setelah pemberian penyuluhan. Saran yang dapat diberikan bagi pihak sekolah hendaknya turut aktif dalam menyampaikan informasi mengenai PHBS kepada anak sekolah.

\section{DAFTAR PUSTAKA}

Almatsier S. Prinsip Dasar Ilmu Gizi. Jakarta: Gramedya Pustaka Utama; 2009

Amrah. Perkembangan moral anak usia sekolah dasar. Jurnal Publikasi Pendidikan. 2013; 3(1): 20-25.

Asirah, Saifuddin. 2014. Hubungan Pola Konsumsi Pangan Sumber Zat Besi dengan Kadar Hemoglobin Anak Sekolah Dasar Negeri Cambaya Kecamatan Ujung Tanah Kota Makassar Tahun 2014. Skripsi Prodi Ilmu Gizi Fakultas Kesehatan Masyarakat. Universitas Hasanuddin. Makassar

Citrakesumasari. Anemia Gizi Masalah dan Pencegahannya. Yogyakarta: Kalika; 2012

Galani, Saifuddin. 2014. Hubungan Karakteristik Sosial Ekonomi Dan Asupan Makan Pagi Dengan Status
Gizi Pada Anak Sekolah Dasar Negeri Cambaya Kecamatan Ujung Tanah Kota Makassar Tahun 2014. Skripsi Prodi Ilmu Gizi Fakultas Kesehatan Masyarakat. Universitas Hasanuddin. Makassar.

Gani, H. 2013. Perilaku Hidup Bersih dan Sehat (PHBS) pada Masyarakat Using di Kabupaten Bayuwangi. Jurnal IKESMAS, Vol 9. No 2. 2013.

Jahari, A.B. 2003. Pemantauan Pertumbuhan Balita. Pusat Penelitian dan Pengembangan Gizi dan Makanan. Jakarta

Kemendikbud. 2012. Pedoman Pelaksanaan UKS di Sekolah. Jakarta: Kemendikbud

Kementerian Kesehatan RI. 2008. Hasil Riset Kesehatan Dasar Indonesia 2013.

Kementrian Kesehatan RI. 2014. Profil Kesehatan Indonesia 2014.

Krianto, Tri. 2009. Perilaku Hidup Bersih Sehat dengan Pendekatan Partisipatif. Jurnal Kesehatan Masyarakat Nasional, 3 (6), hal 254-258.

Murdiastuti D. 2010. Peran Guru Kelas Dalam Meningkatkan Pelaksanaan Belajar Pendidikan Agama Islam Pada Murid di SDN Kalongan. Yogyakarta: Fakultas Ilmu Agama Islam Universitas Islam Indonesi

Nadimin 2004, Pengaruh Suplementasi Besi, Vitamin A dan Vitamin C Sekali Seminggu Terhadap Peningkatan Kadar Hemoglobin danKognitif pada Anak Sekolah Dasar di Kelurahan Pannampu Kecamatan Tallo Kota Makassar. Tesis. Program Pascasarjana Universitas Hasanudin, Makassar.

Nirmala D. Gizi Anak Sekolah. Jakarta Penerbit Buku Kompas; 2012

Notoatmodjo, Soekidjo. 2003. Pendidikan Dan Perilaku Kesehatan. Rineka. Cipta. Jakarta

Pramono, M. 2011. Peningkatan Pengetahuan tentang PHBS dan 
Penyakit Menular Melalui Teknik KIE Berupa Permainan Elektronik. Jurnal Buletin Penelitian Sistem Kesehatan Vol-14, No.4: 311-319

Sinaga T. Ilmu Gizi Teori \& Aplikasi. Jakarta: EGC; 2016.

Sugirah, Saifuddin. 2014. Hubungan Pola Konsumsi Pangan Sumber Zink Dengan Status Zink Anak Sekolah Dasar Negeri Cambaya Kecamatan Ujung Tanah kota Makassar 2014. Skripsi Prodi Ilmu Gizi Fakultas Kesehatan Masyarakat. Universitas Hasanuddin. Makassar

Tanaka N, Miyoshi M. School lunch program for health promoting among children in Japan. Asia Pac J Clin Nutr. 2012; 21(1): 155-158.

Tasbih, Saifuddin. 2014. Hubungan Infestasi Kecacingan Dengan Status Gizi Pada Anak Sekolah Dasar Negeri Cambaya Di Wilayah Pesisir Kecamatan Ujung Tanah Kota Makassar Tahun 2014. Skripsi Prodi Ilmu Gizi Fakultas Kesehatan Masyarakat. Universitas Hasanuddin. Makassar Tribowo, C dan M. Pusphandani. 2015. Ilmu Kesehatan Masyarakat. Yogyakarta: Nuha Medika. 